\title{
Música e som em três documentários brasileiros curta-metragem de 1959: nacionalismos, tradição, modernismos e identidade brasileira
}

\author{
Luíza Beatriz A. M. Alvim*
}

\begin{abstract}
Resumo: Analisamos características sonoras comuns a três documentários curtasmetragens brasileiros de 1959 ( $O$ mestre de Apipucos e $O$ poeta do Castelo, de Joaquim Pedro de Andrade e Arraial do Cabo, de Paulo Cezar Saraceni e Mário Carneiro): O uso de música preexistente ao longo de todo ou quase todo o filme, em especial, peças de Villa-Lobos e Bach, voz over e pouco ou nenhum ruído. Após mapeamento de cada trecho de música, consideramos evocações de nacionalismos, modernismos, tradição e identidade brasileira trazidas tanto pelas associações dos sons com as imagens quanto por aspectos da música em si.

Palavras-chave: música; som; documentário; nacionalismo; modernismo; identidade.
\end{abstract}

Resumen: Analizamos características sonoras comunes a três cortometrajes documentales brasileños de 1959 (O mestre de Apipucos y O poeta do Castelo, de Joaquim Pedro de Andrade, y Arraial do Cabo, de Paulo Cezar Saraceni y Mário Carneiro): el uso de música preexistente a lo largo de toda o casi toda la película, en especial, piezas de Villa-Lobos y Bach, voz over y poco o ningún ruido. Después de cartografiar cada fragmento de música, consideramos las evocaciones de nacionalismos, modernismos, tradición e identidad brasileña proporcionadas tanto por la asociación de los sonidos con las imágenes como por aspectos de la propia música.

Palabras clave: música; sonido; documental; nacionalismo; modernismo; identidad.

\begin{abstract}
Here I analyse sound aspects common to three Brazilian short documentaries of 1959 ( $O$ mestre de Apipucos and O poeta do Castelo, by Joaquim Pedro de Andrade, and Arraial do Cabo, by Paulo Cezar Saraceni and Mário Carneiro): the use of preexistent music through all or almost all the duration of the film, specially, with pieces by Villa-Lobos and Bach, voiceover and few or no sounds. After mapping each musical extract, we consider the evocations of nationalisms, modernisms, tradition and Brazilian identity proportioned by the association of sound and image, as well by aspects of the music piece itself.

Keywords: music; sound; documentary; nationalism; modernism; identity.
\end{abstract}

Résumé: Nous analysons les caractéristiques sonores communes à trois court-métrages documentaires brésiliens de 1959 (O mestre de Apipucos et $O$ poeta do Castelo,

* Pós-doutoranda. Universidade Federal do Rio de Janeiro, Escola de Música, Programa de Pós-Graduação em Música. 20021-290, Rio de Janeiro, Brasil. E-mail: luizabeatriz@yahoo.com

Submissão do artigo: 27 de maio de 2017. Notificação de aceitação: 22 de julho de 2017 .

Doc On-line, n. 22, setembro de 2017, www.doc.ubi.pt, pp. 163-184. 
de Joaquim Pedro de Andrade, et Arraial do Cabo, de Paulo Cezar Saraceni et Mário Carneiro) : en l'occurence, l'utilisation de musique préexistante au long de tout ou presque tout le film, et, particulièrement, de pièces de Villa-Lobos et Bach, voice over et peu ou aucun bruit. Après une cartographie de chaque extrait de musique, nous considérons les évocations de nationalismes, de modernismes, de la tradition et de l'identité brésilienne en correspondance avec l'association du son et de l'image, ainsi qu'avec les aspects de la musique elle-même.

Mots-clés : musique ; son ; documentaire ; nationalisme ; modernisme ; identité.

Em três curtas-metragens brasileiros do ano de 1959 - O mestre de Apipucos e $O$ poeta do Castelo, de Joaquim Pedro de Andrade, e Arraial do Cabo, de Paulo Cezar Saraceni e Mário Carneiro - considerados precursores do Cinema Novo, observamos um traço comum: o uso de música preexistente, em especial, peças do compositor brasileiro Heitor Villa-Lobos (1887-1959) e do compositor barroco alemão Johann Sebastian Bach (1685-1750).

Villa-Lobos foi o único compositor a ter participado da Semana de Arte Moderna de 1922 em São Paulo, marco do Modernismo brasileiro, e, nos curtas-metragens em questão, estão presentes outros personagens do Modernismo: o poeta Manuel Bandeira (em O poeta do Castelo) e o sociólogo Gilberto Freyre, autor do famoso livro Casa Grande e Senzala, a respeito da formação da população brasileira e a questão da escravidão (em $O$ mestre de Apipucos). Além disso, há uma discussão sobre modos de vida tradicional em meio à industrialização na localidade de Arraial do Cabo do documentário homônimo.

A banda sonora como um todo desses filmes de 1959 mostra características comuns com os primeiros curtas-metragens de cineastas franceses nos anos 50: feitos com orçamento pequeno, sonorizados principalmente na pósprodução com comentário over e compilações de músicas preexistentes. Foi assim com Operação concreto (Opération beton, 1954), documentário e primeiro curta-metragem de Jean-Luc Godard, com música de Handel e Bach, e a ficção Bérénice (1954), de Éric Rohmer, com música de Beethoven.

No caso dos curtas-documentários brasileiros, o emprego frequente (e quase total no caso de Arraial do Cabo) de peças de Villa-Lobos aponta justamente para a grande presença da música do compositor nos filmes dos anos 60 do Cinema Novo, em que funcionava, tal qual observado por Irineu Guerrini Júnior (2009), como uma "alegoria da pátria", em especial, no longa-metragem de Glauber Rocha de 1964, Deus e o Diabo na terra do sol.

Em vida, Villa-Lobos foi responsável pela trilha musical do filme de Humberto Mauro de 1937, O descobrimento do Brasil, mas o Cinema Novo leva a uma "redescoberta" do compositor e do próprio Brasil, já iniciada nos curtas- 
Música e som em três documentários brasileiros curta-metragem de 1959:

metragens a serem aqui analisados. Por outro lado, em relação à presença de peças de Bach, tão importante nesses curtas quanto as de Villa-Lobos, é preciso observar que o compositor alemão foi evocado pelo brasileiro como uma das fontes de sua série Bachianas Brasileiras, numa conjugação de nacionalismo e universalismo.

A partir da análise dos elementos sonoros desses curtas-metragens em conjunção com as imagens, vamos neles considerar as relações entre nacionalismos e modernismos, importantes para questionamentos sobre a identidade brasileira. Levamos em conta também aspectos relacionados com o contexto original das músicas em si, considerando que traços desses significados resvalam em sua apropriação pelo cinema. Observamos ainda a relação do uso desses elementos sonoros em comparação ao que acontece no cinema moderno e ao que era característico do cinema clássico.

\section{Villa-Lobos, o nacional e o universal}

O Nacionalismo na obra de Villa-Lobos é, muitas vezes, atribuído como resultado das temporadas do compositor em Paris (a primeira, com início em 1923), quando, longe do país natal, ele se distancia do estilo impressionista e próximo a Debussy de sua obra anterior (Guérios, 2003a) e se apropria mais de elementos nacionalistas, "tornando-se brasileiro em Paris" (Guérios, 2003a: não paginado). Antes disso, na Semana de Arte Moderna de 1922, Villa-Lobos foi o único compositor presente, tendo sido convidado não por ser um músico nacionalista, mas sim, de "vanguarda".

Para efeito de classificação, Ricardo Tacuchian (1988) propôs quatro fases na obra de Villa-Lobos: uma primeira fase de formação até 1919; a segunda, na década de 20: a da vanguarda modernista dos Choros; a terceira (1930-1945), a da criação das Bachianas Brasileiras, corresponde a uma tentativa de síntese do nacional com o universal; e a quarta fase, a partir de 1945, correspondente ao "universalismo" na obra do compositor.

Tacuchian (1988) faz a ressalva de que essas fases não são compartimentos estanques. Assis (2005) também observa que, numa primeira fase do modernismo musical brasileiro, nos anos 10-20, houve grande influência das principais tendências vanguardistas da Europa, sendo que algumas delas eram conjugadas com ideias nacionalistas, pois "ser nacional significava ser moderno e nesta fase inaugural, praticamente todo modernista foi nacionalista e todo nacionalista, modernista" (Assis, 2005: 29).

A série Bachianas Brasileiras traz em seu nome uma homenagem e inspiração no compositor barroco alemão Johann Sebastian Bach, já presente nos 12 Estudos para violão de Villa-Lobos (evocando os famosos estudos de Cho- 
pin para piano, que, por sua vez, evocam os 24 prelúdios e fugas do Cravo Bem Temperado de Bach) da década de 20, assim como nos 5 Prelúdios de 1940, também para violão, que estão presentes nos filmes analisados nesse trabalho.

Há, nessa homenagem, uma relação antropofágica com questões nacionais que apareciam já na apropriação feita pelo Romantismo alemão do compositor barroco. Cem anos após sua morte, Bach estava esquecido no cenário musical e foi um compositor romântico, Felix Mendelssohn, que passou a reger e a popularizar a Paixão de São Mateus a partir de 1829. Desta forma, Bach foi transformado numa figura central da autoconsciência nacional e da identidade alemã, bem ao gosto nacionalista da época (Rueb, 2001). Por outro lado, na virada para o século XX, o compositor passou a significar "progresso" (Rueb, 2001:41).

Contando a história à sua maneira, Villa-Lobos aventou uma suposta afinidade de Bach com a música nacional brasileira, evocando uma "universalidade" de sua música. Segundo o compositor, as Bachianas Brasileiras foram "inspiradas no ambiente musical de Bach, fonte folclórica universal, rica e profunda, com todos os movimentos populares de todos os países, intermediária de todos os povos" (Guérios, 2003b: 168).

Em relação à conjugação de nacional e universal, Mário de Andrade (1972) observou que a suíte (peça característica do período barroco, constituída por uma série de danças, tal como é a sua tradução nas Bachianas Brasileiras), está também presente na música interior do Brasil. Por esse motivo, como constatou Arcanjo (2008), ele a considerou como um instrumento adequado para um compositor brasileiro fazer música "universalisante".

A conformidade com certo "projeto de nação" presente na obra de VillaLobos foi uma das principais razões elencadas por Guerrini Júnior (2009) para a apropriação de suas peças musicais pelo Cinema Novo, que apostava na busca de uma identidade nacional como proposta de superação do subdesenvolvimento. Outra razão, segundo o autor, foi o acesso facilitado às gravações existentes no mercado pela viúva de Villa-Lobos. Tal apropriação já aconteceu desde os três curtas precursores do movimento, como veremos aqui.

\section{O díptico de Joaquim Pedro de Andrade: tradição, modernismos e nacionalismos}

Joaquim Pedro de Andrade foi uma figura essencial do Cinema Novo brasileiro. Em 1957, fundou a produtora Saga Filmes, junto com Sérgio Montana e Gerson Tavares. Com a Saga Filmes e financiamento do Instituto Nacional do Livro, filmou, em 1959, os curtas-metragens documentários $O$ poeta do Castelo e $O$ mestre de Apipucos. Na verdade, como observa Luciana Araújo 
Música e som em três documentários brasileiros curta-metragem de 1959: nacionalismos, tradição, modernismos e identidade brasileira

(2013), os dois foram concebidos e realizados como um só curta, mas logo houve um desmembramento em partes separadas e foi a esse formato que tivemos acesso para a nossa análise.

É preciso dizer que já havia uma conexão de base de Joaquim Pedro de Andrade com o modernismo e a cultura brasileira, representados por esses personagens dos seus primeiros curtas. O diretor era filho de Rodrigo Mello Franco de Andrade, "guardião do tesouro modernista" (Bentes, 1996: 3), fundador, junto com Mário de Andrade e Gustavo Capanema, do Serviço do Patrimônio Histórico e Artístico Nacional (SPHAN). A casa da família era frequentada por figuras importantes do modernismo brasileiro, como Carlos Drummond de Andrade, Lúcio Costa, Vinícius de Moraes, além do próprio Manuel Bandeira, que era padrinho de crisma de Joaquim Pedro (Bentes, 1996). Gilberto Freyre também fazia parte do círculo de amizades de seu pai, estando o nome de Rodrigo M. F. de Andrade num agradecimento, no final do prefácio da primeira edição de Casa Grande \& Senzala (Araújo, 2013).

Embora não fosse exclusividade de Joaquim Pedro de Andrade, dentro do grupo do Cinema Novo, a ligação com a literatura brasileira e com o modernismo dos anos 1920 (Paschoa, 2004), ele e, em especial, seus dois curtasmetragens de estreia representam, por excelência, a relação com essa tradição.

Quanto à forma geral dos documentários em si, observamos que os personagens são captados em atividades de seu cotidiano. Diferentemente da voz over onisciente, bastante comum em documentários até então - considerados por Bill Nichols (2005) como característicos de um "modo expositivo" -, são as vozes dos próprios documentados que narram um texto produzido por eles, tal como foram solicitados pelo diretor: no caso de Gilberto Freyre, um texto narrando o seu cotidiano e, no de Manuel Bandeira, constituído inteiramente por poemas do escritor.

Tal procedimento de Joaquim Pedro de dar voz aos retratados tem semelhanças com o que acontecia no chamado cinema-verdade do cineasta francês Jean Rouch, que começava a se desenvolver no final dos anos 50, como em $E u$, um negro (Moi, un noir, 1958), em que os documentados criaram o texto em voz over enquanto assistiam às imagens captadas. O cinema-verdade de Rouch também lançava mão de procedimentos de encenação durante a filmagem.

Embora o trabalho de Rouch já fosse conhecido, Joaquim Pedro de Andrade não teve um contato mais profundo com ele na época dos seus primeiros curtas-metragens, pois só foi à França em 1961, com uma bolsa para estudar no IDHEC (Institut des Hautes Études Cinématographiques). Foi com um estágio seguinte, em Nova York, que o diretor conheceu outros documentaristas importantes da época, os irmãos Maysles, e o assim chamado "cinema direto". 
Característico do "modo observativo" de Nichols (2005), no cinema direto não há entrevistas, mas sim a captação de uma situação em seu todo de imagem e som. Para isso, foi muito importante o surgimento do gravador Nagra 3, que permitiu a captação do som direto.

$O$ poeta do castelo e $O$ mestre de Apipucos, porém, foram feitos antes da chegada do Nagra 3 ao Brasil ${ }^{1}$ e seus elementos sonoros (em que se destacam a música e a voz over) foram colocados na pós-produção, numa "aceitação do limite tecnológico" (Resende, 2007: 35) da época. Mesmo assim, há uma preocupação de Joaquim Pedro em sonorizar O poeta do Castelo com ruídos do cotidiano.

Em relação à música, tanto $O$ poeta do Castelo quanto $O$ mestre dos Apipucos tiveram sua trilha musical escolhida por Zito Batista e Carlos Sussekind. Ambos os filmes contam com uma peça de Villa-Lobos e uma de Bach, assim como os créditos dos dois estão ao som de parte da Introdução da Suíte n.1, O Descobrimento do Brasil, de Villa-Lobos (estamos, como mencionado, levando em conta o formato separado em dois curtas-metragens).

Essas características já nos revelam aspectos importantes. Os créditos, por exemplo, tornam clara a filiação reivindicada mais tarde pelo Cinema Novo à figura de Humberto Mauro, além de associar os dois personagens capitais da cultura nacional retratados pelos documentários (Manuel Bandeira e Gilberto Freyre) a um terceiro, Villa-Lobos. O próprio caráter gráfico dos créditos remetem a uma "estética modernista" e Araújo (2013) observa que o estilo era semelhante ao do Suplemento Dominical do Jornal do Brasil. A relação com o Modernismo também estará nos créditos de Arraial do Cabo, sobre gravuras de Oswaldo Goeldi.

Além disso, o fato de contarem tanto com uma peça de Villa-Lobos (Prelúdio/Modinha das Bachianas Brasileiras $n .1$ no início do Poeta do Castelo e o Prelúdio $n .2$ para violão em $O$ mestre de Apipucos) quanto com uma de Bach (o Quinto Concerto de Brandenburgo BWV 1050, em O poeta do Castelo, e o Concerto para violino e oboé em dó menor BWV 1060, em O mestre de Apicucos) também aponta para a relação já mostrada no ítem anterior entre Villa-Lobos e o compositor barroco alemão.

Vamos investigar com mais detalhes as sequências desses filmes. Além de Villa-Lobos e Bach, há peças de outros compositores do repertório preexistente, seja brasileiro, como Alberto Nepomuceno, ou internacional, como Gabriel Fauré e Paul Bowles.

1. Um marco para isso foi o curso realizado pelo sueco Arno Sucksdorff no Rio de Janeiro, em 1962-1963. 
Música e som em três documentários brasileiros curta-metragem de 1959:

\subsection{O mestre de Apipucos}

A banda sonora de $O$ mestre de Apipucos é constituída inteiramente pela voz over de Gilberto Freyre e peças musicais (tabela 1), uma se seguindo à outra, na totalidade do filme (o início de cada uma é geralmente indicado por olhares do protagonista ou raccords de movimento), sem sonorização com ruídos.

Tabela 1. Peças musicais em O mestre de Apipucos.

\begin{tabular}{|c|c|c|}
\hline Tempo & Peça musical & Imagem e voz over \\
\hline 0’46”- 1'52”' & $\begin{array}{l}\text { Suíte n.1 Descobrimento do Brasil } \\
\text { de Villa-Lobos Introdução }\end{array}$ & Créditos iniciais \\
\hline 1'53”- 2’22”' & $\begin{array}{l}\text { Música de coro misto não identifi- } \\
\text { cada }^{2}\end{array}$ & $\begin{array}{l}\text { Casarão. Passeio matinal } \\
\text { no jardim. }\end{array}$ \\
\hline 2'22” - 3'22”' & Música orquestral não identificada & Passeio matinal no jardim \\
\hline 3'22”- 4'32” & $\begin{array}{l}\text { Adagio do Concerto para violino e } \\
\text { oboé em dó menor BWV 1060, de } \\
\text { Bach. }\end{array}$ & Na biblioteca \\
\hline 4'33'”- 5'43”' & Música orquestral não identificada & Toma café com a mulher. \\
\hline $5 ' 48^{\prime \prime}-63^{\prime}$, & $\begin{array}{l}\text { Sonata para violino n.l em sol me- } \\
\text { nor, Sicilliana de BACH- Segovia. }\end{array}$ & $\begin{array}{l}\text { Vai para a porta da cozi- } \\
\text { nha e olha para fora. Plano } \\
\text { seguinte: o mar e Gilberto } \\
\text { Freyre na praia. }\end{array}$ \\
\hline $63^{\prime} 43^{\prime \prime}-83^{\prime \prime}$ & $\begin{array}{l}\text { Prelúdio } n .2 \text { para violão de Villa- } \\
\text { Lobos }\end{array}$ & $\begin{array}{l}\text { Ele na cozinha observando } \\
\text { o trabalho da empregada ao } \\
\text { fogão. Ele próprio prepara } \\
\text { uma bebida. }\end{array}$ \\
\hline 8'17'" - 9’01” & $\begin{array}{l}\text { Sesta na rede (terceira parte da Sé- } \\
\text { rie Brasileira), de Alberto Nepo- } \\
\text { muceno }\end{array}$ & $\begin{array}{l}\text { Deitado na rede, com o ga- } \\
\text { to. }\end{array}$ \\
\hline
\end{tabular}

A segunda incursão musical começa com o primeiro plano do filme, o casarão de Apipucos. ${ }^{3}$ É uma peça de coro misto, que traz um significado religioso e, desta maneira, relaciona-se com a fala over de Gilberto Freyre sobre o trecho musical seguinte, que menciona "os meus vizinhos, os maristas, acordam cantando". Porém, ao mesmo tempo em que se configura uma função referencial da música, bastante comum no cinema clássico (Gorbman, 1987), assim

2. Entramos em contato com a família de Joaquim Pedro de Andrade, mas, infelizmente, não há material de produção em que essas peças estejam identificadas. Também não foi possível com a nossa escuta, nem com a utilização de diferentes programas de computador.

3. Apipucos é o bairro de Recife onde ficava a casa de Gilberto Freyre. 
como uma tentativa de simular uma música diegética, justificada no mundo narrativo, por outro lado, o fato de ser o coro "misto" não condiz com o que se esperaria de uma congregação de irmãos, em que tenderíamos a ouvir canto gregoriano em uníssono de vozes masculinas.

A emenda da música coral com a música orquestral seguinte se faz de maneira fluida tanto no som quanto na imagem (com raccord de movimento, quando Gilberto Freyre abaixa uma folha em plano-detalhe com a bengala). Não identificamos também essa música, mas ela apresenta semelhanças com peças escritas para cinema em sequências passadas no campo, com uso de intrumentos como o oboé. Mais uma vez, a música funciona de maneira referencial ao local: o jardim.

Já a peça seguinte, o Adagio do Concerto para violino e oboé em dó menor $B W V 1060$ de Bach, ajuda a corroborar o que tanto as imagens do filme quanto a narração de Gilberto Freyre denotam: o sociólogo como um grande intelectual, possuidor de imenso tesouro cultural (pensamos, aqui, na associação da música de Bach com uma suposta tradição cultural universal ${ }^{4}$ ) em suas estantes (ele diz: "Os livros, espalhados por várias salas, chegam a 20 mil"). Além disso, a presença de Bach aponta para a associação deste compositor a Villa-Lobos, cujo Prelúdio $n .2$ será ouvido mais adiante.

Ouvimos, a seguir, uma música orquestral (também não identificada) de andamento rápido e com um caráter alegre, que combina com a felicidade do momento de convívio familiar cotidiano, quando Gilberto Freyre toma café com sua mulher. ${ }^{5}$

No momento em que Freyre, à porta da cozinha, olha para fora, começa a Sicliana da Sonata para violino $n .1$ de Bach em transcrição para violão de Andrès Segóvia, havendo uma elipse, pois, no plano seguinte, vemos o mar e o escritor na praia da Boa Viagem.

Embora a tonalidade principal da sonata de Bach seja sol menor, seu terceiro movimento, a Siciliana, está na tonalidade relativa maior, Si bemol maior. Para Joel Lester (1999), a tonalidade maior é um dos motivos de sua leveza, além de enfatizar o seu caráter de dança. No entanto, Lester também observa que alguns importantes violinistas a interpretam destacando a mesma seriedade presente nos outros movimentos da peça. Tal é a nossa impressão quanto

4. Consideramos, em algumas partes do texto, clichês gerais a que são associadas peças musicais preexistentes desde sua utilização como acompanhamento no cinema silencioso, quando se consolidaram vários códigos culturais (Gorbman, 1987) no uso com a imagem. Peças conhecidas do repertório "clássico universal", como a citada música de Bach, trazem à tona uma assocação com a tradição cultural do passado ocidental.

5. Essa sequência, em que aparece Manuel, o empregado, de libré, foi um dos motivos por que Gilberto Freyre e sua mulher Magdalena não gostaram do filme, pois estariam sendo apresentados como esnobes. Magdalena observou que a sequência foi completamente encenada e irreal em relação aos verdadeiros hábitos da família (Araújo, 2013). 
Música e som em três documentários brasileiros curta-metragem de 1959: nacionalismos, tradição, modernismos e identidade brasileira

ao arranjo para violão de Segóvia e à interpretação que ouvimos no filme: certa lentidão e gravidade, e, talvez por isso, uma melancolia (presente já nos primeiros quatro compassos, mesmo antes dos compassos 5 e 6 , em que a música vai para sol menor ${ }^{6}$ ) nas imagens de Gilberto Freyre na praia, sozinho.

Ainda ouvimos os últimos compassos do trecho da Siciliana quando vemos o escritor passando a mão na barriga: a "deixa" para a indicação da fome e a volta para o ambiente da cozinha da casa. Na imagem do peixe sendo frito, os últimos sons da Siciliana são emendados com os do Prelúdio $n .2$ para violão de Villa-Lobos.

Levando-se em conta essas duas últimas peças, ambas para violão, é importante considerar a presença do instrumento em si. Na Espanha, o violão teve vários compositores e virtuoses no século XX, como Andrès Segovia, autor da transcrição. No caso do Brasil, o instrumento era execrado no meio erudito do início do século XX por ser associado à marginalidade. Acabou se tornando um símbolo de brasilidade e teve em Villa-Lobos um de seus maiores difusores e reabilitadores. De fato, no final do século XIX, o violão havia sido adotado pelos nascentes conjuntos de choro no Rio de Janeiro, sendo construída, com isso, uma associação do instrumento como "manifestação musical própria dos setores marginais da sociedade" (Taborda, 2004: .61). Villa-Lobos foi fascinado desde cedo pelos chorões e estudou violão escondido da família, mas o seu pioneirismo foi o de levar o violão, no Brasil, ao status de instrumento de concerto, com peças escritas originalmente para ele, como os estudos e prelúdios (Amorim, 2007).

O Prelúdio para violão $n .2$ de Villa-Lobos tem como título "Homenagem ao homem capadócio" e contém justamente uma série de elementos que remetem ao choro, como o caráter brejeiro (Amorim, 2007). No filme, a sua primeira parte, em que esses elementos estão mais presentes, é ouvida duas vezes: primeiramente, sobre as imagens de Gilberto Freyre observando a cozinheira no preparo do peixe; depois, quando ele mesmo prepara "uma batida de pitanga, maracujá e hortelã", culinária e bebida típicas locais (uma evocação de elementos próprios de uma identidade local e, por que não, brasileira).

A última peça musical do filme, Sesta na rede, da Suíte Brasileira (18871897) de Alberto Nepomuceno (um dos primeiros compositores brasileiros a escreverem obras numa estética considerada nacionalista) aponta também para esse caráter nacional brasileiro, além de que seu título se remete com função

6. Lester (1999) divide a Siciliana, de maneira geral, em três partes, cada uma delas começando com o motivo principal da tríade ascendente: do compasso 1 ao 4, na tonalidade principal de Si bemol maior; do 4 ao 9, em sol menor; do 9 ao 19, com uma coda nos compassos 19-20. 
referencial ${ }^{7}$ ao que acontece na imagem: o escritor se balança numa rede após o almoço, na compainha de seu gato. O balançar da rede é evocado, na música, pelo naipe de cordas, com os graus conjuntos ascendentes em legato da viola, seguido do acorde de $\mathrm{V}$ grau arpejado e stacatto dos violinos, além do balanço entre o V e o I grau. Tal "balanço" é comumente evocado como um elemento de brasilidade na peça.

O último plano mostra a capa do livro que Gilberto Freyre está lendo: Poesias, de Manuel Bandeira. Era o gancho para o começo da parte sobre o poeta, antes do desmembramento dos dois curtas-metragens.

\subsection{O poeta do Castelo}

Na tabela 2, vemos o esquema dos trechos musicais em $O$ poeta do Castelo.

Tabela 2. peças musicais em O poeta do Castelo

\begin{tabular}{|c|c|c|}
\hline Tempo & Peça musical & Imagem e voz over \\
\hline 0'40" - 1'17' & $\begin{array}{l}\text { Suíte n.1 "Descobrimento do Bra- } \\
\text { sil" de Villa-Lobos, Introdução }\end{array}$ & Créditos iniciais \\
\hline 1'18' - 3'00'” & $\begin{array}{l}\text { Prelúdio/Modinha (II) das Bachia- } \\
\text { nas Brasileiras } n .1 \text { de Villa-Lobos. }\end{array}$ & $\begin{array}{l}\text { Bandeira no beco do Cas- } \\
\text { telo. Prédios. Poema "Be- } \\
\text { lo Belo". }\end{array}$ \\
\hline 4'55" - 6'22" & $\begin{array}{l}\text { Pavane para orquestra e flauta op. } \\
50, \text { de Gabriel Fauré }\end{array}$ & $\begin{array}{l}\text { Bandeira à janela, depois } \\
\text { na biblioteca. }\end{array}$ \\
\hline 6'23”' - 8' & $\begin{array}{l}\text { Affettuoso (II), do Quinto Concerto } \\
\text { de Brandenburgo BWV } 1050 \text { de } \\
\text { Bach. }\end{array}$ & Bandeira no quarto. \\
\hline 8'00” - 8'52”' & $\begin{array}{l}\text { Allegro (III), do Quinto Concerto de } \\
\text { Brandenburgo BWV } 1050 \text { de Bach }\end{array}$ & $\begin{array}{l}\text { Bandeira levanta da cama } \\
\text { e começa a recitar "Passár- } \\
\text { gada". }\end{array}$ \\
\hline 8'52" até fim & $\begin{array}{l}\text { Music for a Farce, Allegro (IV), de } \\
\text { Paul Bowles }\end{array}$ & $\begin{array}{l}\text { Bandeira na rua. Continua } \\
\text { a recitar "Passárgada" }\end{array}$ \\
\hline
\end{tabular}

Embora os créditos de $O$ poeta do Castelo tenham como trilha musical a mesma peça de Villa-Lobos (e o mesmos grafismos) presente em $O$ mestre de Apipucos, é interessante que, aqui, a transição para o Prelúdio (Modinha) das Bachianas n.1, também de Villa-Lobos, mal se faça notar, dando uma maior continuidade ao que se segue. Em parte, tal sensação de continuidade pode

7. Outro elemento curioso é a menção de Freyre, em seu comentário over, que ele se deita numa "rede do Ceará", tendo sido o compositor também cearense. 
Música e som em três documentários brasileiros curta-metragem de 1959: nacionalismos, tradição, modernismos e identidade brasileira

ser explicada por ser uma peça do mesmo compositor, mas, além disso, há características semelhantes de textura (cordas, na Suíte n.1, com parte da melodia desenvolvida pelos violoncelos, instrumentos para os quais foi escrita a Bachianas n.1), rítimicas, melódicas e de andamento (Andante, em ambas as peças).

Assim, depois dos créditos iniciais, enquanto ouvimos a progressão cromática ascendente a partir da nota fá sustenido do compasso 11 do Prelúdio (Modinha), vemos Manuel Bandeira caminhar da esquerda para a direita por um beco do Castelo ${ }^{8}$ até uma mercearia, onde entrega uma garrafa vazia. O tema pungente e lírico em tom menor, a partir do compasso 14, começa no plano próximo de Bandeira, logo após a sua tosse (cujo som não ouvimos) e corrobora o sentimento de melancolia perante a finitude, indicada pela tosse e pela idade avançada do poeta. O plano seguinte, o chão cheio de papeis e lixo, também se relaciona com uma sensação de decrepidude. Depois disso, vários planos dos prédios vazios, destacando a sua arquitetura, imagens que reforçam ainda mais a melancolia e a solidão.

Esses sentimentos são propiciados mais ainda porque a música é o único elemento sonoro em todo esse início do filme. É somente depois, no plano de Bandeira na mercearia recebendo a garrafa com leite, quando o poeta olha para o céu como que buscando inspiração, que ouvimos os primeiros versos do poema Belo Belo: "Belo belo minha bela/ Tenho tudo que não quero/ Não tenho nada que quero". A beleza mencionada no verso inicial de Bandeira contrasta com as imagens de lixo até aí e as seguintes, em que vemos o poeta caminhando por entre os prédios num beco, ao passo em que o sentimento de frustração dos outros versos também está em sinergia com essas imagens.

Como observa Airton Paschoa (2004), todo esse trecho inicial do filme faz referência a outra obra de Bandeira, o Poema do Beco, de 1933, em que o poeta descrevia a visão que tinha da janela de seu quarto, num beco da região da Lapa (e não do Castelo, como nas imagens do filme), onde morava na época. Isso evidencia a conexão do material fílmico com a própria obra literária de seu retratado para além dos poemas recitados no curta-metragem.

O corte do trecho do Prelúdio/Modinha de Villa-Lobos coincide com o término dessa sequência inicial e o começo da seguinte, em que vemos Bandeira em seu apartamento. Diferentemente de $O$ mestre de Apipucos, temos, então, quase dois minutos sem música, só com os sons e as imagens do cotidiano de Bandeira, caracterizado pela simplicidade e pela solidão, além de sua voz over recitando seu poema Testamento. O caráter cotidiano dessa sequência é mar-

8. O Castelo é uma localidade no centro da cidade do Rio de Janeiro, onde, antes da reforma dirigida por Pereira Passos, no início do século XX, havia o Morro do Castelo, que foi derrubado. 
cado por uma série de ações prosaicas sonorizadas: Bandeira, de roupão, pega uma panela, derrama o leite, acende um fósforo, sopra a boca do fogão para aumentar o fogo, coloca ali a panela, pega duas fatias de pão no armário e as põe na torradeira, o leite ferve, as torradas ficam prontas, o poeta coloca o leite numa xícara, põe sua refeição sobre a mesa e abre a janela. Como observa Flores (2015), essa exposição do cotidiano está em consonância com a proposta do Cinema Novo de focar seus personagens na vida comum do dia-a-dia. Embora essa proposta esteja evidente também no curta anterior, em $O$ poeta do Castelo há uma aproximação maior com o Neo-realismo italiano, como observa Araújo (2013), por conta do olhar afetuoso e demorado sobre ações banais.

Flores (2015: 17, tradução nossa do espanhol) considera que essas duas primeiras sequências do filme denotam a presença "do novo e do velho que caracterizariam a arte modernista representada por Bandeira: a visita ao leiteiro (e não a um grande mercado), assim como o seu sopro para avivar o fogo se contrapõem com o uso de aparelhos modernos como a torradeira". Essa união do tradicional e do novo está também em muitas das músicas escolhidas para o filme. É o caso da já citada peça de Villa-Lobos, compositor que, a grosso modo, faz uma releitura da tradição europeia representada por Bach (este, por sua vez, com duas obras no filme), conferindo cores locais, assim como da peça que estará na sequência seguinte, a Pavana para orquestra e flauta op.50 de Fauré.

A pavana é uma dança europeia do período renascentista, com origem italiana ou espanhola (de acordo com as fontes), tendo sobrevivido como forma musical no Barroco e sido comum na França do século XVII. No final do século XIX, Gabriel Fauré a retomou, tal como fizeram outros compositores franceses da época, Ravel e Debussy. Além de uma volta à tradição musical do passado, a Pavana op.50 de Fauré representou, como observa Ricon (2014: 387), uma reação a um cenário musical francês de final de século XIX dominado por compositores germânicos, com um retorno àquilo "considerado plenamente nacional" (no caso, nacional francês).

No filme de Joaquim Pedro, a Pavana de Fauré começa ainda no plano de Bandeira à janela de sua cozinha. Uma panorâmica para a esquerda, efetuada num tempo bastante condizente com o andamento lento da música, vai nos revelar outra janela da casa do poeta, a de sua biblioteca, que ele abre a seguir. Vemos, então, Bandeira pegando um livro de uma estante sobre a qual está seu próprio busto. A câmera faz várias panorâmicas da biblioteca, destacando grandes estantes e armários plenos de livros e obras de arte. A Pavana de Fauré também corrobora o peso da tradição das imagens do acervo cultural (universal, diríamos, embora não possamos ler os títulos) encarnado nos livros 
Música e som em três documentários brasileiros curta-metragem de 1959:

da biblioteca de Bandeira, numa sequência que, em significado, aproxima-se da presente no curta sobre Gilberto Freyre.

A panorâmica que inicia a passagem da janela da cozinha à biblioteca, junto com a música de Fauré, marca o momento de uma reconsideração por parte do espectador sobre a figura de Manuel Bandeira, assim como aponta para a reencenação da própria trajetória de vida do poeta efetuada pelo curtametragem. Ao chegarmos à biblioteca, deixamos de ver um homem humilde e solitário, como o poeta da Lapa dos anos 30: não é mais o poeta do beco, mas sim o artista reconhecido de 1959, é o Poeta do Castelo. Assim, nesse momento do filme "nos damos conta de que o curta operou um largo recuo temporal" (Paschoa, 2004: 152) até o poeta humilde do beco, recuo no tempo que a panorâmica e a música de Fauré vão desfazer.

A sequência seguinte se passa no quarto de Bandeira (com um rápido plano de sua varanda) e tem como trilha musical dois movimentos, Affettuoso (II) e Allegro (III), do famoso Quinto Concerto de Brandenburgo BWV 1050 de Bach. Também aqui a tradição cultural representada tanto pela música de Bach como por Bandeira é destacada: vemos, inicialmente, o poeta do Castelo trabalhando em sua cama, ao lado de uma estante com livros, ao som do Affettuoso de Bach, de andamento lento e melodia pungente.

Enquanto Bandeira está em sua cama com a máquina de datilografar no colo e ao som do Affetuoso, outro som é ouvido, destacando um elemento da modernidade do século XX: o telefone. O poeta atende e dá uma risada, que não ouvimos. Joaquim Pedro de Andrade (1966) conta ter sido a risada do poeta, tão ouvida quando ele frequentava a sua casa, a motivadora dessa sequência. $\mathrm{O}$ diretor também explicita o caráter encenado dela e atribui a não sincronização perfeita da campainha do telefone com a imagem a seu montador:

Às quartas-feiras, ele [Bandeira] vinha jantar com meu pai [...]. Vinha então aquela risada alegre que eu quis pôr no filme e acabou resultando na única cena que o ator Manuel Bandeira teve dificuldade de fazer.[...]

Fizemos um ensaio. Manuel riu sem vontade. No segundo e terceiro ensaios o ator se irritava cada vez mais, quando ria. Experimentamos então o estímulo real. Manuel telefonou a um amigo, Dante Milano, se não me engano, para pedir que ele lhe telefonasse de volta. Mas o Dante não estava. Quando começamos a procurar outro amigo, no caderninho de telefones do poeta, ele perdeu a paciência. Mandou rodar a câmera, atendeu o telefone que não tinha tocado, perguntou quem estava falando e ao ouvir a risada imaginária deu a risada, mais alegre e espontânea do que nunca. Guardo mágoa, até hoje, porque a campainha do telefone continuou tocando, no filme, mesmo depois do poeta ter tirado o fone do gancho. A culpa foi do montador Baldacconi, que num momento de mau humor resolveu me hostilizar dessa maneira insólita (Andrade, 1966: não paginado). 
Pouco depois que Bandeira desliga o telefone, assim que desiste de continuar trabalhando (ele afasta a tábua com máquina de datilografar) e se levanta para trocar de roupa, começa o Allegro de Bach. $\mathrm{O}$ andamento mais rápido da música combina com a série de ações de Bandeira arrumando-se para sair de casa. O poeta confirma que "irá embora" ao recitar os primeiros versos de seu famoso poema Passárgada: "Vou-me embora pra Pasárgada/ Lá sou amigo do rei/ Lá tenho a mulher que eu quero/ Na cama que escolherei/ Vou-me embora pra Pasárgada// Vou-me embora pra Pasárgada/ Aqui eu não sou feliz/".

Joaquim Pedro de Andrade (1966) conta que a alegria da risada era o elemento que, segundo o roteiro, impulsionava o poeta para a ascenção a Passárgada no fim do filme. Mais do que ela, não sendo ouvido o som da risada, Airton Paschoa (2004: 153) observa que o ruído do telefone, "insistente, reproduz o chamado do mundo, Passárgada e sua promessa de felicidade terrestre".

A felicidade no filme é bem simples: o prazer de comprar um jornal, de encontrar um amigo na rua e de andar pelas ruas do centro do Rio de Janeiro, próximas ao apartamento dele. Sua voz over continua recitando o poema Passárgada. É, porém, importante lembrarmos, como salientamos anteriormente, que Bandeira já aparece para o espectador como um poeta reconhecido e não é à toa que o vemos passando em frente à Academia Brasileira de Letras, de que já fazia parte há quase 20 anos.

A peça musical que acompanha tudo isso desde a primeira imagem da sequência (os jornais e revistas da banca) é o quarto movimento, Allegro, de Music for a Farce, peça de 1938 de Paul Bowles para clarineta, trompete, piano e percussão. $\mathrm{O}$ andamento rápido, o caráter brejeiro dado em parte pelo ritmo e pelos timbres da clarineta e do trompete e os traços jazzísticos são características comuns e costumeiramente associadas, no uso de música no cinema, a um ambiente urbano.

Paul Bowles foi um escritor e compositor americano que estudou com Aaron Copland, fez parte do círculo de Gertrud Stein em Paris e passou a viver definitivamente no Marrocos a partir de 1947, tendo sido sua casa um ponto de encontro da geração beat ${ }^{9}$. Bowles fez parte, portanto, dos modernismos literários e musicais do século $\mathrm{XX}$, que, de certa maneira, infiltram-se na última sequência do filme de Joaquim Pedro.

9. Foi no Marrocos que ambientou seu livro mais conhecido, $O$ céu que nos protege, adaptado para o cinema por Bernardo Bertollucci. 
Música e som em três documentários brasileiros curta-metragem de 1959:

\section{Arraial do Cabo: o violão de Villa-Lobos como símbolo de brasilidade e modos de vida tradicionais}

Arraial do Cabo foi dirigido por Paulo Cezar Saraceni, produzido por Joaquim Pedro de Andrade e sua montagem ficou a cargo de Mário Carneiro, o fotógrafo do filme. Foi Mário Carneiro quem colocou a trilha musical, feita quase que completamente com obras de violão de Villa-Lobos e, por conta desse grande papel no resultado final do filme, foi creditado também como diretor (Saraceni, 1993). Sobre a música, Saraceni conta:

Eu tinha pensado em colocar no filme as músicas que ouvíamos muito nos alto-falantes das ruas de Arraial. Eram músicas de Lindomar Castilho, Jackson do Pandeiro, como aquela do fim do filme, chamada "Aurora" 10 , no bar do Juca. Mas Mário me mostrou os exercícios para violão de Villa-Lobos, os choros de Villa-Lobos, e como eram lindos! (Saraceni, 1993: 55).

O filme trata das mudanças ocasionadas entre pescadores da cidadezinha de Arraial do Cabo, no Rio de Janeiro, pela instalação de uma fábrica de álcalis. Há um texto over, escrito por Claudio Mello e Souza e lido pelo ator Ítalo Rossi, admirado por Saraceni justamente porque "não tem voz de narrador, nem é impostada" (Saraceni, 1993: 55), como habitual nos documentários da época. O filme foi realizado sem som direto, embora se note uma fascinação de Saraceni pelos ruídos locais - o que lembra bastante o fascínio de Godard pelos ruídos da construção de uma barragem em seu primeiro curta, Operação concreto (sendo que Godard contou com a pesada aparelhagem de som direto da época) - e o diretor tenha lamentado muito a falta do Nagra (Saraceni, 1993).

Essa presença dos ruídos marca a anunciação da chegada do "progresso" com o caminhão (e seu som) percorrendo as ruas que antes eram atravessadas somente por um cavalo, além das imagens a seguir da fábrica de álcalis, seus ruídos e sons de bateria ${ }^{11}$. Tudo isso é ouvido assim que a música da primeira sequência (o Prelúdio n.1 de Villa-Lobos, tabela 3) se cala.

10. Parece se tratar da peça Aurora gravada por Nelson de Castro e Orquestra Tupã no disco Esquentou o baile, de 1959. Porém, não conseguimos o áudio dela para confirmar.

11. Em Terra em transe (1967), Glauber Rocha também utilizou sons de bateria para indicar agressividade (Alvim, 2015). 
Tabela 3. peças musicais em Arraial do Cabo

\begin{tabular}{|c|c|c|}
\hline Tempo & Peça musical & Imagem e voz over \\
\hline 0' - 1'03' & Não identificada & $\begin{array}{l}\text { Créditos - imagens de Go- } \\
\text { eldi }\end{array}$ \\
\hline 1'03” - 2'52”' & $\begin{array}{l}\text { Prelúdio n.1 em mi menor para } \\
\text { violão de Villa-Lobos }\end{array}$ & $\begin{array}{l}\text { Homem tomam café. Mu- } \\
\text { lheres carregam baldes de á- } \\
\text { gua. Barcos e os pescadores. } \\
\text { Mulheres em suas atividades } \\
\text { diárias. }\end{array}$ \\
\hline 3'43”- 4'08' & $\begin{array}{l}\text { Estudo n. } 8 \text { de Villa-Lobos, In- } \\
\text { trodução }\end{array}$ & $\begin{array}{l}\text { (Depois da menção à fábri- } \\
\text { ca no comentário) Os pesca- } \\
\text { dores se afastam para praias } \\
\text { mais distantes. }\end{array}$ \\
\hline 5'55”- 7’38”' & $\begin{array}{l}\text { Prelúdio n.4 em mi menor de } \\
\text { Villa-Lobos }\end{array}$ & Atividades dos pescadores \\
\hline 7’38'” - 8'48' & $\begin{array}{l}\text { Estudo n.1, Animé, de Villa- } \\
\text { Lobos, em mi menor }\end{array}$ & Atividades dos pescadores \\
\hline $8^{\prime} 48^{\prime \prime}-11^{\prime} 17^{\prime \prime}$ & $\begin{array}{l}\text { Estudo n.11 em mi menor, de } \\
\text { Villa-Lobos, parte Animato e } \\
\text { Lento final. }\end{array}$ & Atividades dos pescadores \\
\hline $11^{\prime} 17^{\prime \prime}-12{ }^{\prime} 23^{\prime \prime}$ & $\begin{array}{l}\text { Sonata para violino n.1 em } \\
\text { sol menor, Sicilliana de BACH- } \\
\text { Segovia. }\end{array}$ & Atividades dos pescadores \\
\hline $12{ }^{\prime} 23^{\prime \prime}-13^{\prime} 43^{\prime \prime}$ & $\begin{array}{l}\text { Estudo n.5, Andantino, em Dó } \\
\text { Maior, de Villa-Lobos }\end{array}$ & Atividades dos pescadores \\
\hline $13^{\prime} 44^{\prime \prime}-15^{\prime} 11^{\prime \prime}$ & $\begin{array}{l}\text { Estudo } n .8 \text { em dó \# menor de } \\
\text { Villa-Lobos, parte depois da } \\
\text { introdução }\end{array}$ & $\begin{array}{l}\text { Atividades dos pescadores. } \\
\text { Voz over. }\end{array}$ \\
\hline 15'19" até fim & $\begin{array}{l}\text { Aurora, Nelson de Castro e Or- } \\
\text { questra Tupã (?) }\end{array}$ & $\begin{array}{l}\text { Após pescador ligar o rádio } \\
\text { no bar. Homem discursa. }\end{array}$ \\
\hline
\end{tabular}

Na primeira sequência, portanto, vemos atividades cotidianas da comunidade de Arraial ao som da música de Villa-Lobos. O Prelúdio 1 em mi menor tem o título de "Homenagem ao sertanejo brasileiro" e, no filme, vai funcionar como evocação saudosista daquele modo de vida "primitivo" (mesmo que sem deixar de expor suas mazelas) em vias de desaparição pela chegada do progresso. Ele tem uma forma tripartita $\mathrm{ABA}$ e, no filme, ouvimos um pedaço da primeira parte A e a parte B seguinte. Na parte A, Villa-Lobos explora a região grave do violão (Amorim, 2007) e a tonalidade menor dá um sentido melancólico às imagens, que revelam a penúria daqueles habitantes: o desjejum re- 
Música e som em três documentários brasileiros curta-metragem de 1959:

sumido a uma xícara de café numa casa de parede esburacada e a necessidade de se buscar água num poço e carregá-la em latas na cabeça, os barcos em que os pescadores se lançam à batalha diária. Na parte $\mathrm{B}$ do prelúdio, há a evocação de um ponteio de viola (Amorim, 2007): a música adquire um caráter de dança e vemos principalmente as mulheres em sua atividade diária de passar e costurar assim como meninas dançando em roda.

Essa dualidade tradição (Villa-Lobos ${ }^{12}$ ) X progresso (ruídos) continua com a breve incursão da Introdução do Estudo $n .8$ de Villa-Lobos sobre as imagens dos pescadores e de um barco. Essa introdução, assim como a parte A do Prelúdio 1 analisada anteriormente, está no registro grave do violão e é bastante modulante, apontando para a necessidade de mudança dos pescadores para lugares mais afastados, evocada pelo narrador. A seguir, voltamos a ouvir o som de bateria e a ver as imagens da fábrica. Tal som permanece ainda sobre imagens do barco e dos pescadores, como se indicasse uma batalha entre o antigo e o novo. Então, são ouvidos vários sons maquínicos, não necessariamente sincrônicos com as imagens.

Até que, depois de alguns sons de burburinho e vozes dos pescadores, começamos a ouvir o Prelúdio n.4 de Villa-Lobos. Daí até quase o final do filme teremos vários estudos para violão de Villa-Lobos e a mesma Siciliana de Bach na transcrição de Segovia, já utilizada em $O$ mestre de Apipucos (tabela 3). Como relata Amorim (2007), Villa-Lobos encontrou Segovia pela primeira vez em 1924 em Paris, dedicou a ele seus Estudos e esse contato fez com que rasgueios e outros elementos típicos do violão espanhol tenham se incorporado à escrita de alguns deles.

Além disso, observamos que, com a presença dessa peça, Arraial do Cabo também coloca em evidência a relação de Villa-Lobos com Bach (passando por Segovia), como nos dois curtas-metragens de Joaquim Pedro. Por outro lado, a predominância de peças de violão no documentário como um todo - especialmente os prelúdios e estudos de Villa-Lobos - em associação às atividades tradicionais dos habitantes de Arraial do Cabo evoca aspectos de brasilidade (embora, na verdade, o violão, originalmente, fosse associado a uma identidade mais urbana e carioca, à modernidade).

Analisamos, então, a grande sequência que começa com o Prelúdio $n .4$ e vai até os 15 minutos de filme. Como os prelúdios 1 e 2 de Villa-Lobos, o Prelúdio n.4 também tem uma "homenagem" em seu título, agora ao "índio

12. Chamamos a atenção de que, aqui, estamos considerando a música de Villa-Lobos, com seu resgate de elementos da identidade brasileira, como associada a modos de vida tradicionais brasileiros, de que faz parte a pesca com rede dos habitantes de Arraial do Cabo (e não como a tradição da "música clássica universal", tal qual evocamos anteriormente quanto à música de Bach). É em oposição à pesca tradicional e à música de Villa-Lobos que o documentário apresenta os ruídos e a modernidade da fábrica de álcalis. 
brasileiro". É ouvido desde o seu início, lento, e, como as peças anteriores, também no registro grave do instrumento e em mi menor, sobre imagens do mar, dos pescadores preparando a rede e de um pescador fumando e observando a paisagem. Vem a sua parte $\mathrm{B}$, Animato, com arpejos muito rápidos e as imagens mostram os pescadores com movimentos apenas um pouco mais rápidos que os das atividades anteriores, até que a parte $\mathrm{A}^{\prime}$ (A modificada, com altura mais aguda) volta a imagens e gestos mais contemplativos. Alterna-se novamente com arpejos rápidos, agora do Estudo n.1 de Villa-Lobos, também em mi menor, sobre imagens também com um pouco mais de movimento (pescadores correndo, puxando seu barco, remando, mexendo nas redes e fazendo sinais da terra para os companheiros no mar). A transição para a parte Animato do Estudo $n .11$ é bem fluida, até porque o trecho ouvido também é mi menor. É a volta dos pescadores do mar, finalizada no Lento do estudo.

Depois dessas alternâncias lento-rápido geralmente na tonalidade de mi menor, a emenda, exatamente na nota si bemol, é com a Siciliana de BachSegóvia, no caso, com sua segunda parte, que começa no compasso 4, com o motivo principal do arpejo ascendente, indo para o tom de sol menor, até o começo da volta para a tonalidade maior principal nos compassos 10 e 11 . Aqui, diferentemente do que evoca o trecho em Si bemol Maior no filme de Joaquim Pedro de Andrade, mesmo com a tonalidade menor, a Siciliana resvala uma leveza - característica observada por Lester (1999) -, uma sensação de tranquilidade condizente com a aparente "vitória" dos pescadores sobre a natureza, com imagens de muitos peixes nas redes, homens sorrindo e crianças participando desse final de dia.

Ouvimos, a seguir, o Estudo n.5 em Dó maior com as imagens de grandes peixes em planos detalhe. O Estudo n.5 é escrito a três vozes, sendo a sua voz central constituída por um ostinato (começando cada ciclo com a nota sol, como a tonalidade do trecho anterior da Siciliana), que dá um caráter de inexorabilidade à prática tradicional da pescaria e à agonia dos peixes morrendo. Quando a voz superior vai para um registro mais agudo para construir a melodia, passamos a ver uma alternância de planos médios e próximos de pescadores conversando entre si. Essa coincidência da música com a troca de ênfase das imagens mostra, mais uma vez, o grande cuidado que houve na montagem por parte de Mário Carneiro. Com o término da condução melódica no agudo, vemos mais imagens dos homens e crianças na praia ao fim do dia.

Junto com o Estudo n.8, que, diferente das outras transições, promove um grande contraste já a partir da tonalidade bem distante, temos a volta da voz over. Ela anuncia o processo de salga dos peixes retirados do mar, que vemos nas imagens seguintes do documentário, iniciando-se com dois planos de pei- 
Música e som em três documentários brasileiros curta-metragem de 1959:

xes sendo puxados. A parte do Estudo $n .8$ que ouvimos é a mais melódica, depois de sua introdução (presente no início do documentário).

Assim, a música de Villa-Lobos utilizada nessa sequência, além da já referida associação à brasilidade, por efeito do registro predominante do grave do instrumento e pela tonalidade de mi menor na fase da busca dos peixes, confere também um caráter épico a todas essas atividades cotidianas dos pescadores.

O final do filme tem uma música de banda (provavelmente a Aurora mencionada por Saraceni, do repertório da Orquestra Tupã), vinda do rádio do bar onde se reúnem os pescadores. Ela destaca o caráter provinciano de Arraial do Cabo e evoca os bailes comuns nas pequenas cidades brasileiras.

\section{Considerações finais}

Observamos, a partir da análise da música (tanto considerando a sua relação com as imagens do filme, quanto em associações simbólicas mais gerais das peças em si que resvalam nos filmes) e dos sons presentes nos curtasdocumentários brasileiros O poeta do Castelo, O mestre de Apipucos e Arraial do Cabo, todos de 1959, evocações de elementos relacionados à identidade brasileira, de aspectos relacionados a nacionalismos (seja um nacionalismo brasileiro, como no caso de Villa-Lobos e Nepomuceno, ou, no caso de Bach e de Gabriel Fauré, de nacionalismos alemão e francês, respectivamente) e de questionamentos já presentes na época da Semana de Arte Moderna de 1922 (a relação do nacional com o universal e do moderno com a tradição).

Consideramos que a escolha de um determinado repertório é essencial para trazer esses questionamentos à tona. Por exemplo, a presença da música de Villa-Lobos nos três documentários, especialmente por conta de sua inspiração no compositor barroco alemão J. S. Bach - ele próprio elevado como símbolo da identidade germânica no século XIX, sendo que sua música foi, por vezes, aqui considerada como representante de uma tradição cultural, em sua associação com imagens de bibliotecas e livros -, expõe a relação, já considerada em análises da obra como um todo de Villa-Lobos (como em Tacuchian, 1988), do nacional com o universal.

A noção de modernismo também se faz complexa e é por isso que deixamos a palavra no plural no título. Tais documentários são precursores do Cinema Novo, um dos movimentos do cinema moderno brasileiro, e possuem várias características em comum com ele, como a presença da música de VillaLobos (na função de "alegoria da pátria", como na análise de Guerrini Jr, 2009), a relação com o Modernismo de 1922 (sugerida, entre outras coisas, pela figura de Manuel Bandeira no curta-metragem de Joaquim Pedro de An- 
drade e pela música de Villa-Lobos) e a ênfase no cotidiano dos desvalidos (em Arraial do Cabo).

Por outro lado, em Arraial do Cabo, as peças de Villa-Lobos utilizadas, todas elas para violão, associam-se às atividades cotidianas e tradicionais (como a pesca com rede) dos habitantes da vila de pescadores. Deste modo, embora não seja uma música ligada a uma tradição popular rural (apesar das fontes populares em que Villa-Lobos se inspirou em sua obra como um todo, o violão se insere nela por suas fontes urbanas: a música do chorões do Rio de Janeiro), em nossa análise, nós a consideramos como do lado da tradição e resvalando significados de brasilidade, mesmo que também contando com elementos característicos do violão espanhol. Em oposição a ela, estão os ruídos e as imagens das máquinas, símbolo de um progresso irreversível e deletério para aquelas pessoas, atadas a modos de vida tradicionais.

Ainda em relação à música e ao som nos três documentários, observamos que, de maneira semelhante a outros curtas-metragens do final dos anos $50 \mathrm{e}$ indicando uma tendência comum no cinema moderno dos anos 60 , há o uso de música preexistente como trilha musical. No entanto, tal característica aponta também para uma certa restrição de recursos (o pagamento e gravação de uma orquestra ou instrumentista implicaria em mais gastos) e limitações tecnológicas, também presentes no uso predominante do elemento sonoro da voz over em detrimento dos ruídos, colocados na pós-produção.

A presença da voz over assim como alguns modos de utilização da música (por exemplo, usos bastante referenciais, especialmente em $O$ mestre de Apipucos) nos remetem ao cinema clássico narrativo. Porém, de modo mais próximo às produções do documentário moderno, a voz dos curtas-metragens de Joaquim Pedro de Andrade pertence aos próprios retratados e a voz do narrador de Arraial do Cabo se cala na maior parte do filme e não é impostada como a voz onisciente e onipresente nos documentários clássicos.

\section{Referências bibliográficas}

Alvim, L. (2015). A música de Villa-Lobos nos filmes de Glauber Rocha dos anos 60: alegoria da pátria e retalho de colcha tropicalista. SignificaçãoRevista de Cultura Audiovisual, (42)

Amorim, H. (2007). Heitor Villa-Lobos: uma revisão bibliográfica e considerações sobre a produção violonística. Rio de Janeiro: Dissertação de Mestrado em Música, Universidade Federal do Estado do Rio de Janeiro.

Andrade, J. P. (17 abril 1966). O poeta filmado. Diário de Notícias (Suplemento Literário). Disponível em: www.filmesdoserro.com.br/bio59_b.a sp. 
Música e som em três documentários brasileiros curta-metragem de 1959:

Andrade, M. de (1972). Ensaio sobre a música brasileira. São Paulo: Vila Rica.

Araújo, L. C. de (2013). Joaquim Pedro de Andrade: primeiros tempos. São Paulo: Alameda.

Arcanjo, L. (2008). O ritmo da mistura e o compasso da história: o modernismo musical nas Bachianas Brasileiras de Heitor Villa-Lobos. Rio de Janeiro: E-papers.

Assis, A. C. (2005). Os doze sons e a cor nacional: conciliações estéticas e culturais na produção musical de César Guerra-Peixe (1944-1954). Belo Horizonte: Tese de Doutorado em História, Universidade Federal de Minas Gerais.

Bentes, I. (1996). Joaquim Pedro de Andrade: a revolução intimista. Rio de Janeiro: Relume-Dumará.

Flores, S. (2015). Escritos breves: testimonios audiovisuales de Brasil. Revista Imagofagia, (12).

Gorbman, C. (1987). Unheard melodies: narrative film music. Londres: BFI.

Guérios, P. R. (2003a). Heitor Villa-Lobos e o ambiente artístico parisiense: convertendo-se em um músico brasileiro. Mana, 9 (1).

Guérios, P. R. (2003b). Heitor Villa-Lobos: o caminho sinuoso da predestinação. Rio de Janeiro: Editora FGV.

Guerrini Jr, I. (2009). A música no cinema brasileiro: os inovadores anos sessenta. São Paulo: Terceira Margem.

Lester, J. (1999). Bach's works for solo violin: style, structure, performance. Oxford: Oxford University Press.

Nichols, B. (2005). Introdução ao documentário. Campinas: Papirus.

Paschoa, A. (set/nov 2004). A estreia de Joaquim Pedro: gigante adormecido e Bandeira popular. Revista USP, (63): 144-156.

Resende, L. A. (jan./jun. 2007). Ruptura e continuidade no documentário brasileiro: 1959-1962. Alceu, 7 (14).

Ricon, L. (jul./dez. 2014). O menino e os sortilégios: apontamentos sobre a presença da Primeira Guerra na obra de Maurice Ravel (1914-1930). História: Debates e Tendências, 14 (2): 380-394

Rueb, F. (2001). 48 variações sobre Bach. São Paulo: Compainha das Letras.

Saraceni, P. C. (1993). Por dentro do Cinema Novo: minha viagem. Rio de Janeiro: Nova Fronteira. 
Taborda, M. E. (2004). Violão e identidade nacional: Rio de Janeiro 1830/ 1930. Rio de Janeiro: Tese de Doutorado em História Social, Universidade Federal do Rio de Janeiro.

Tacuchian, R. (1988). Villa-Lobos e Stravinsky. Revista do Brasil: edição especial Villa-Lobos, 4 (1). Rio de Janeiro.

\section{Filmografia}

O descobrimento do Brasil (1937), de Humberto Mauro.

Bérénice (1954), de Éric Rohmer.

Operação concreto (Opération beton, 1954), de Jean-Luc Godard.

Eu, um negro (Moi, un noir, 1958), de Jean Rouch.

O mestre de Apipucos (1959), de Joaquim Pedro de Andrade.

$O$ poeta do Castelo (1959), de Joaquim Pedro de Andrade.

Arraial do Cabo (1959), de Paulo Cezar Saraceni e Mário Carneiro.

Deus e o Diabo na terra do sol (1964), de Glauber Rocha.

Terra em transe (1967), de Glauber Rocha. 